\title{
Innate immune responses in RNA viral infection
}

\author{
Qian $\mathrm{Xu}^{1,2}$, Yuting Tang ${ }^{1}$, Gang Huang $(\bowtie)^{1}$ \\ ${ }^{1}$ Divisions of Pathology and Experimental Hematology and Cancer Biology, Cincinnati Children's Hospital Medical Center, Cincinnati, OH \\ 45229, USA; ${ }^{2}$ Department of Hematology, Tongji Hospital, Tongji Medical College, Huazhong University of Science and Technology, Wuhan \\ 430030, China \\ (C) The Author(s) 2020. This article is published with open access at link.springer.com and journal.hep.com.cn
}

\begin{abstract}
RNA viruses cause a multitude of human diseases, including several pandemic events in the past century. Upon viral invasion, the innate immune system responds rapidly and plays a key role in activating the adaptive immune system. In the innate immune system, the interactions between pathogen-associated molecular patterns and host pattern recognition receptors activate multiple signaling pathways in immune cells and induce the production of pro-inflammatory cytokines and interferons to elicit antiviral responses. Macrophages, dendritic cells, and natural killer cells are the principal innate immune components that exert antiviral activities. In this review, the current understanding of innate immunity contributing to the restriction of RNA viral infections was briefly summarized. Besides the main role of immune cells in combating viral infection, the intercellular transfer of pathogen and host-derived materials and their epigenetic and metabolic interactions associated with innate immunity was discussed. This knowledge provides an enhanced understanding of the innate immune response to RNA viral infections in general and aids in the preparation for the existing and next emerging viral infections.
\end{abstract}

Keywords innate immune; viral infection; intercellular signaling; metabolic changes; epigenetic changes

\section{Introduction}

An RNA virus is a virus that uses RNA as its genetic material; it could be single-stranded RNA (ssRNA) or double-stranded RNA (dsRNA) [1]. Retroviruses are not generally considered RNA viruses because they use DNA intermediates to replicate. However, they have a singlestranded RNA genome. Notable human diseases caused by RNA viruses include coronavirus disease 2019, severe acute respiratory syndrome (SARS), Ebola virus disease, common cold, influenza, hepatitis $\mathrm{C}$, hepatitis $\mathrm{E}$, rabies, polio, and measles. RNA viruses generally have higher mutation rates than DNA viruses due to the lack of proofreading ability of the RNA polymerases in contrast to DNA polymerases, hindering the development of optimal vaccines to prevent the diseases caused by RNA viruses.

Upon viral infection, the innate immune system acts as the first line to prevent the spread of the invading pathogens and plays a crucial role in triggering the adaptive immunity. The innate immune cells could recognize the conserved features discriminately expressed

Received August 2, 2019; accepted March 14, 2020

Correspondence: Gang Huang, Gang.Huang@cchmc.org by the virus but not on the host cells as pathogenassociated molecular patterns (PAMPs). Through interactions with PAMPs, the pattern recognition receptors (PRRs) expressed by innate immune cells activate several intracellular signaling pathways and induce the production of type I interferons (IFNs) and pro-inflammatory cytokines to initiate the antiviral responses of the host $[2,3]$. In a prototypical response to an acute viral infection, the clearance of viral-infected cells is expected to be achieved within a few weeks. However, some viruses develop strategies to inhibit or evade the host immune responses that favor their replication and cause persistent infection in the host. The molecular mechanisms, under which the viruses evade the antiviral immune responses and establish their persistence in the host, remain to be further investigated.

The interactions between the invading virus and the innate immunity are complex, and they consist of multiple layers. This review highlighted the recognition and defense mechanisms adopted by innate immune cells against RNA viral infection, with a focus on cell type-specific cellular responses. The intercellular transfer of pathogen and hostderived material, which is a newly discovered mechanism affecting the innate immune signaling, was also discussed. Moreover, the epigenetic interactions between the host and 
the RNA viruses were briefly introduced. These interactions are also new to the field, and they broaden the understanding of antiviral responses in innate immunity. Finally, the cellular metabolic alterations affected by the IFN-generated antiviral state, as indicated by recent evidence and previous observations, were explored.

\section{Viral recognition and initiation of antiviral responses}

Upon the invasion of viruses, the innate immune system is the first line of host defense and is rapidly activated. The innate immune cells sense the viral invasion through multiple types of ligand-receptor interaction [4]. PAMPs are conserved structural motifs that could activate innate immunity to protect against infections through recognition of properties derived from viruses or bacteria that distinguish the pathogen components from the host, including nucleic acids, peptides, and lipoproteins. During viral infection, PAMPs could be recognized by host PRRs expressed not only in innate immune cells, such as macrophages, dendritic cells (DCs), and natural killer (NK) cells but also in other cell types, such as epithelial cells. PRRs consist of the membrane-bound type and the cytoplasmic type. The former includes Toll-like receptors (TLRs) and C-type lectin receptors (CLRs), while the latter includes retinoic acid-inducible gene 1 (RIG-I)-like receptors (RLRs), nucleotide oligomerization domainlike receptors (NLRs), and cyclic GMP-AMP synthase (cGAS). This section focused on the PRRs that mediate the signaling responses in innate immune cells during RNA viral infection.

TLRs are a class of transmembrane receptors expressed by antigen-presenting cells (APCs), such as DCs and macrophages, and some types of T cells (Table 1). Unlike the TLRs recognizing bacterial components mainly expressed on plasma membrane, the human TLRs, such as TLR3, TLR7, TLR8, and TLR9, that could recognize viral nucleic acids are expressed exclusively in the endosomal compartment. Double-stranded viral RNA taken up into the endosomes of sentinel cells are sensed by TLR3 [5-8] to recruit the cytoplasmic adaptor protein TIR domain-containing adaptor inducing IFN- $\beta$ (TRIF)dependent downstream signaling pathways. ssRNAs are sensed by TLR7 and TLR8, which utilize MyD88dependent downstream signaling pathways [9]. TLR9 is the only known DNA sensor that recognizes the unmethylated CpG DNA of DNA viruses [10]. However, TLR9-mediated signaling may also play a role during RNA viral infection, as revealed by the recent finding that dengue virus (DENV) infection could induce a release of mitochondrial DNA into the cytosol and activate TLR9 signaling pathways [11].

RLRs are a group of cytosolic RNA helicases that detect
RNA species in the cytoplasm of infected cells [12]. To date, three receptors have been identified: RIG-I, melanoma differentiation-associated gene 5 (MDA5), and laboratory of genetics and physiology 2 (LGP2). These RLR proteins are distinct in their RNA recognition capacities and signaling properties. Functional domains shared by these proteins are the $\mathrm{DExD} / \mathrm{H}$ box RNA helicase domain, which could bind to dsRNA and induce ATP hydrolysis, and the C-terminal domain (CTD), which is associated with binding to RNA termini and autoregulation [13]. Only two N-terminal tandem caspase recruitment domains (CARDs) are presented by RIG-I and MDA5 but not by LGP2, and they are crucial for the activation of downstream signaling. MDA5 senses long dsRNA without unpaired bulged nucleotides, while RIG-I senses short 5' tri- and dephosphorylated dsRNA with base-paired terminal 5' and 3' nucleotides [14-16]. Then, oligomerization of mitochondrial antiviral signaling protein (MAVS) is triggered [17,18]. LGP2 functions as regulators for the other two receptors, inhibiting RIG-I-mediated responses while enhancing MDA5 signaling [19]. This differential effect was recently found to be dependent on a direct protein-protein interaction between the regulatory CTD of LGP2 and the IFN-inducible, double-stranded RNA binding protein PACT [19]. LGP2 is at low levels in uninfected cells but accumulates after the viral infection or due to the treatment of poly(I:C) and IFN [20,21].

CLRs could recognize various carbohydrate ligands with their carbohydrate recognition domains. In addition to the initiation of inflammatory mediator production, pathogen sensing by CLRs may initiate phagocytosis or innate killing depending on the specific CLR and cell type [22]. The mannose receptor (MR) is one type of CLR expressed on macrophages and DCs to recognize mannose, fucose, and $\mathrm{N}$-acetylglucosamine on the surfaces of viruses, bacteria, and parasites [23]. Through its activation, the pathogen could be internalized and targeted to lysosomes for degradation. However, evidence also suggested that DENV utilizes MR to evade the degradation after internalization [24]. Thus, the role of CLRs could either be routing for the degradation or the dissemination of viruses.

The signaling pathways downstream of PRRs lead to the expression and/or activation of transcription factors, such as NF- $\kappa \mathrm{B}, \mathrm{AP}-1$, and interferon regulatory factors (IRFs), which all induce the expression of downstream anti-viral genes, including types I and III IFNs, pro-inflammatory cytokines, and chemokines. These target genes could enhance the adaptive immune response, inhibit pathogen replication, and adapt the host cells to environmental changes [25-29]. Type I IFNs, which are mainly produced by macrophages and DCs [30-32], induce an anti-viral state in the neighboring cells by stimulating the expression of hundreds of genes that are collectively known as IFNstimulated genes (ISGs). The chemokines produced at the 
location of infection could recruit additional immune cells, including neutrophils, monocytes, and NK cells (Fig. 1).

NLRs could detect a wide range of PAMPs and DAMPs. NLR family pyrin domain containing 3 (NLRP3) is an important component of the inflammasome system and the most well-studied NLR. It could be detected in myeloid cell types, including monocytes, macrophages, DCs, and neutrophils [33]. Many pathogens, including DNA and RNA viruses, fungi, and protozoa, could activate the NLRP3 inflammasome and induce the maturation of inflammatory cytokines IL-1 $\beta$ and IL-18 [34-36], resulting in inflammatory pyroptotic cell death and the formation of phagosomes. Some viruses even induce abnormal activation of the inflammasome and aggravate the diseases. SARS coronavirus (SARS-CoV) is an enveloped positivestrand RNA virus that encodes a number of accessory proteins, including open reading frame (ORF) $8 \mathrm{a}, 8 \mathrm{~b}$, and 9b. SARS-CoV triggers robust NLRP3 inflammasome activation and IL-1 $\beta$ release by direct binding of ORF $8 b$ to the LRR domain of NLRP3. The aberrant inflammasome activation and cytokine storm lead to excessive inflammation and enhanced disease [37]. ORF8b and 8ab are also confirmed as novel IFN antagonists that limit IRF3 activation and/or promote proteasome-mediated degradation of IRF3 [38].

A major breakthrough in 2013 discovered cGAS could bind directly to viral DNA, trigger conformational rearrangement, and catalyze cyclic GMP-AMP (cGAMP) synthesis, which activates stimulator of IFN gene (STING)-dependent TBK1-mediated IRF3 axis or IKKsmediated NF- $\kappa \mathrm{B}$ axis $[39,40]$. DNA viruses are targeted by this pathway, while some RNA viruses could manipulate the DNA sensors, such as cGAS/STING, in turn. For example, Zika virus-encoded NS1 protein is able to recruit caspase-1 activation and induce proteolysis of cGAS [41]. This interplay between inflammasome and cGAS/STING pathways facilitates the immune escaping strategy of Zika virus.

\section{Important components shaping innate immune responses: macrophages, DCs, and NK cells}

Within minutes to hours upon the detection of pathogens, tissue-resident macrophages and DCs are activated. Then,

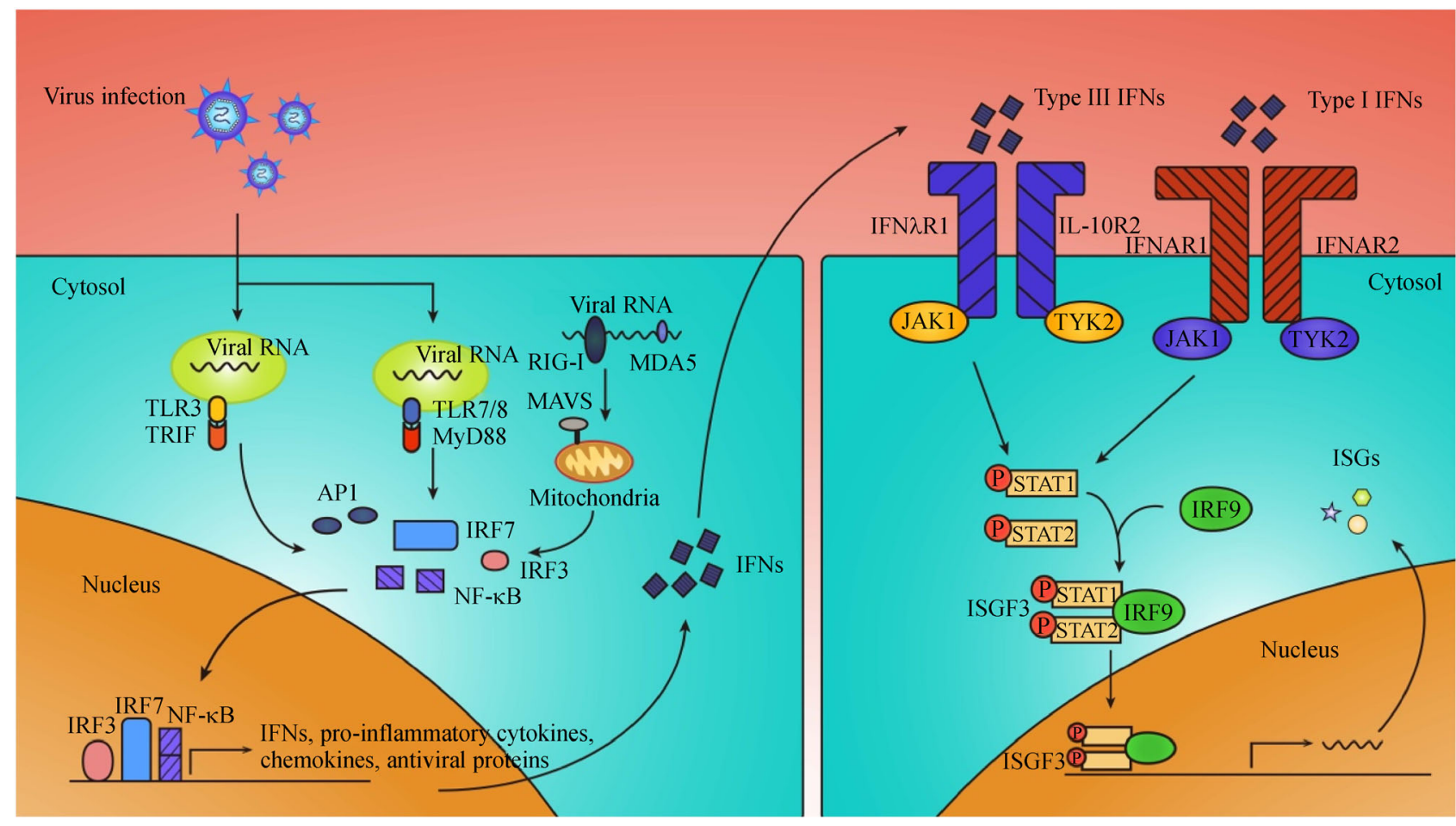

Fig. 1 Schematic of RNA viral signaling pathway. Endosomes expose viral RNAs to TLR3, 7, and 8. The TLR signaling pathways consist of two major cascades, namely, MyD88 and TRIF, depending on TLR domain-containing adaptors. RIG-I and MDA5 could sense RNA in the cytoplasm and trigger the oligomerization of MAVS. These transduction cascades result in IRF3/7 and NF- $\kappa \mathrm{B}$ activation, which induces IFN secretion. Types I and III IFNs are sensed by distinct membrane-bound receptor complexes and stimulate similar signaling pathways. IFNs could activate the transcription of ISGs through intracellular kinases JAK1 and TYK2 and induce signaling pathways through STAT1/STAT2/IRF9 binding to the IFN-stimulated response elements (ISREs) in target gene promoters. Subsequently, a large number of ISGs is activated. 
Table 1 PRRs in innate immune cells and PAMPs

\begin{tabular}{llll}
\hline PRRs & & PAMPs & References \\
\hline TLRs (transmembrane) & TLR1 & Lipoproteins (bacteria) & {$[42,43]$} \\
& TLR2, TLR4 & Structural proteins (capsid, envelope & {$[42-45]$} \\
& TLR3 & proteins) & {$[5-8]$} \\
& TLR5 & dsRNA & {$[46]$} \\
& TLR6 & Flagellin (bacteria) & {$[42]$} \\
& TLR7 & Lipoproteins (bacteria) & {$[9]$} \\
& TLR8 & ssRNA & {$[9]$} \\
& TLR9 & ssRNA & {$[10]$} \\
RLRs (cytoplasm) & TLR10 & CpG motif (bacteria, virus) & {$[17,18]$} \\
& RIG-I & Not determined & {$[17,18]$} \\
NLRs (cytoplasm) & MDA5 & RNA & {$[20,21]$} \\
& LGP2 & RNA & {$[33]$} \\
CLRs (membrane bound) & NLRP3 & RNA & {$[47]$} \\
Others & NLRP1 & DNA, RNA, protein & {$[47]$} \\
\hline
\end{tabular}

the inflammatory cytokines, chemokines, biogenic amines, and eicosanoids produced by these two types of cells recruit additional innate immune cells, including NK cells, neutrophils, and monocytes, to the infection locations.

\section{Macrophages}

Macrophages evolve in the innate immune system and play important roles in the regulation of inflammation and phagocytosis of viruses [48-50]. However, they are also well-known for their "double-edged sword" role in the immune system due to their versatile polarization states, which depend on the converging signals from inflammatory stimuli in the environment. The versatile states exert multiplex functions, including pathogen elimination, proinflammation, and tissue destruction and repair [51,52]. M1 type macrophages, such as M(IFN- $\gamma$ ), M(LPS + IFN$\gamma$ ), and M(LPS) subtypes, present as proinflammatory, tissue-destructive, antitumoral, antimicrobial, and immunogenic macrophages. By contrast, M2 type macrophages such as M(IL-4), M(Ic), M(IL-10), M(GC + TGF- $\beta$ ), and $\mathrm{M}(\mathrm{GC})$ subtypes, are associated with viral persistence and could promote tissue repair in some cases [49,50,52-54].

Macrophages express receptors for all three types of IFNs, which are produced by several innate immune cells during viral infection to induce gene expression in the infected and neighboring uninfected cells. Types I and III IFNs are sensed by the receptors of IFNAR1/IFNAR2 and IFNR $\lambda 1 /$ IL-10R2, respectively, leading to the activation and dimerization of STAT1 and STAT2 [55]. Afterward, IRF9 is recruited to form an IFN-stimulated gene factor-3 complex. This canonical signaling pathway induces ISGs and pro-inflammatory responses featuring an M1 status. In addition, type I IFNs could signal through STAT3 and STAT6 homodimers to induce an M2 status [56,57]. Noncanonical signaling pathways, including mitogen-activated protein kinase cascade and PI3K/Akt/mTOR signaling, could be regulated by either type I or type III IFNs [58-63].

Besides IFNs, some RNA viruses themselves affect the macrophage polarization status and compromise their functions. Some coronaviruses could over-activate macrophages to incite M1-associated inflammation, which causes macrophage depletion via apoptosis and necrosis [64-66]. Meanwhile, the incited acute cytokine storm may also harm the host [67]. Targeting the signaling pathways to moderate the virus-induced cytokine storm protects patients from infection, even without suppressing viral replication [68]. RNA viruses, such as hepatitis $C$ virus (HCV), could upregulate IL-10 expression, which induces M2 polarization of macrophages and shows immunosuppressive effects [69-71]. Therefore, these viruses could suppress the anti-viral responses of the hosts and develop persistent and systemic infections [72,73]. In sum, the future therapeutic strategy against viral diseases could be expanded to regulating the polarization status of macrophages rather than solely focusing on killing the viruses [74-76].

\section{DCs}

As unique immune sentinels, DCs play a crucial role in sensing pathogens and inducing immune responses. They 
are the major APCs in the immune system, and they have different subtypes on the basis of their location, phenotype, and function $[77,78]$. Human DCs can be divided into two groups: myeloid DCs (mDCs) and plasmacytoid DCs (pDCs) [79]. mDCs mainly reside in lymphoid tissues, such as in spleen, thymus, and secondary lymph nodes. They express myeloid antigens (CD11c, CD13, CD33, and $\mathrm{CD} 11 \mathrm{~b})$ and can be further classified into $\mathrm{CD} 1 \mathrm{c}^{+}$and $\mathrm{CD} 141^{+}$DCs. In tissues and lymph nodes, a third subgroup of $\mathrm{mDCs}$ has been detected, and it is defined as interstitial DCs on the basis of CD14 expression. Interstitial DCs were first identified in the interstitium of non-lymphoid organs, and they are closely related to lymphoid DCs. pDCs are a small subset of DCs entering the lymph nodes from the circulatory blood. They do not have myeloid antigens expressed on their membrane. Instead, pDCs express CD123, CD303, and CD304 $[79,80]$.

When exposed to viruses, human DCs sense the molecular patterns through specific receptors, including TLR7 and TLR9, and become mature with the upregulation of CCR7 and MHC molecules. Then, these mature DCs migrate to local-draining lymph nodes and interact with naïve $T$ cells in the secondary lymphoid organs to elicit the adaptive immune response [81].

pDCs play a key role in the early anti-viral responses, primarily because they could produce types I (IFN- $\alpha$ and IFN-b) and III (IFN- $\lambda /$ IL-28/IL-29) IFNs. In addition, activated pDCs produce proinflammatory cytokines, such as tumor necrosis factor $\alpha$ (TNF- $\alpha$ ), IL-6, IL-8, immunomodulatory cytokines, and chemokines. pDCs could also promote the maturation of APCs and activate T cells and NK cells [82]. For some viruses, the resolution of infection is highly correlated with the functions of pDCs. In patients infected with DENV, viral load and disease severity are inversely associated with the number of circulating pDCs and their IFN responses [83].

The role of DC-NK interaction is important in inducing the adaptive immune response to viral infections. MHC class I-related chains A and B (MIC-A/B) expressed on DCs could activate NK cells by transducing positive signals to NK cells. However, chronic HCV-infected DCs, for instance, have decreased MICA/B expression on DCs and production of IL-15. Therefore, patients with chronic HCV infection also have low NK cells $[84,85]$.

\section{NK cells}

NK cells were originally identified by their ability to lyse tumor cells in vitro [86]. The antiviral activities of NK cells consist of the production of proinflammatory cytokines, such as IFN- $\gamma$, and directing lysis of infected cells [87]. NK cells act as a crucial and early source of IFN- $\gamma$, which helps the host defend against viruses by improving the antiviral $\mathrm{T}$ cell responses and increasing the non-cytolytic control of viral replication $[88,89]$. In addition, other cytokines (e.g., TNF- $\alpha$ ), inflammatory chemokines (e.g., RANTES), and growth factors could be generated by NK cells [90,91]. Through secreting chemokines and cytokines, NK cells communicate with their neighboring cells in several immunological processes, including viral defense and immunological homeostasis. The direct lysis of infected cells by NK cells is mediated by antibodydependent cellular cytotoxicity (ADCC). Most NK cells express immunoglobulin G receptor Fc $\gamma$ RIII (CD16), which mediates the interaction with antibody-coated target cells and activates ADCC.

During viral infection, NK cells recognize inflammatory signals using several strategies. The cytokine-cytokine receptor axis plays an important role in the activation of NK cells. The expression of cytokine receptors for IFN- $\alpha$, IL-12, IL-15, and IL-18 are upregulated early after the infection [92]. The above cytokines could provide stimuli to imprint the stable expression of IFN- $\gamma$ in NK cells. The IFN- $\gamma$ expression in NK cells represents their expansion capacity $[93,94]$ and increased cytotoxicity [95]. Moreover, the activation of cytokine receptors protects NK cells from "fratricidal" killing via NK cell population expansion and defense against viruses [96].

The balance between inhibitory and activating receptors expressed on NK cells is modulated during viral infection. The major inhibitory receptors include killer cell immunoglobulin-like receptors (KIRs) and CD94/NKG2A. The binding of these inhibitory receptors to MHC class I molecules maintains the tolerance of NK cells in healthy host cells [97]. During tumor development or viral infection, NK cells detect modified host cells through a "missing self" mechanism (MHC class I protein downregulation), which represents a central regulatory pathway during NK cell activation [98]. NK cells also have activating receptors (e.g., NKG2D, NKG2C, and DNAM-1) expressed on their membrane [97,99-101] that could initiate rapid killing of target cells $[102,103]$. NKG2D could be upregulated by various viral infections and provide an activating signal upon recognition of stressinduced ligands on infected cells [104]. This "inducedself" recognition helps NK cells to clear harmful host cells. However, some viruses could evade the host's immune system by preventing the upregulation of NKG2D ligands expressed on the infected cells [105,106]. NKp46 activates NK cells in response to viral ligands encoded by parainfluenza [107], influenza A virus [108], metapneumovirus [109], and reovirus [110]. NKG2C is only expressed on a specific population of NK cells, which recognize pathogen-derived antigens. Compared with conventional NK cells, NKG2C-positive NK cells expand in patients with $\mathrm{HCV}$ infection or dengue viral infection only when the patients are HCMV-seropositive and display different transcriptomic signatures (Fig. 2) [111-114]. 


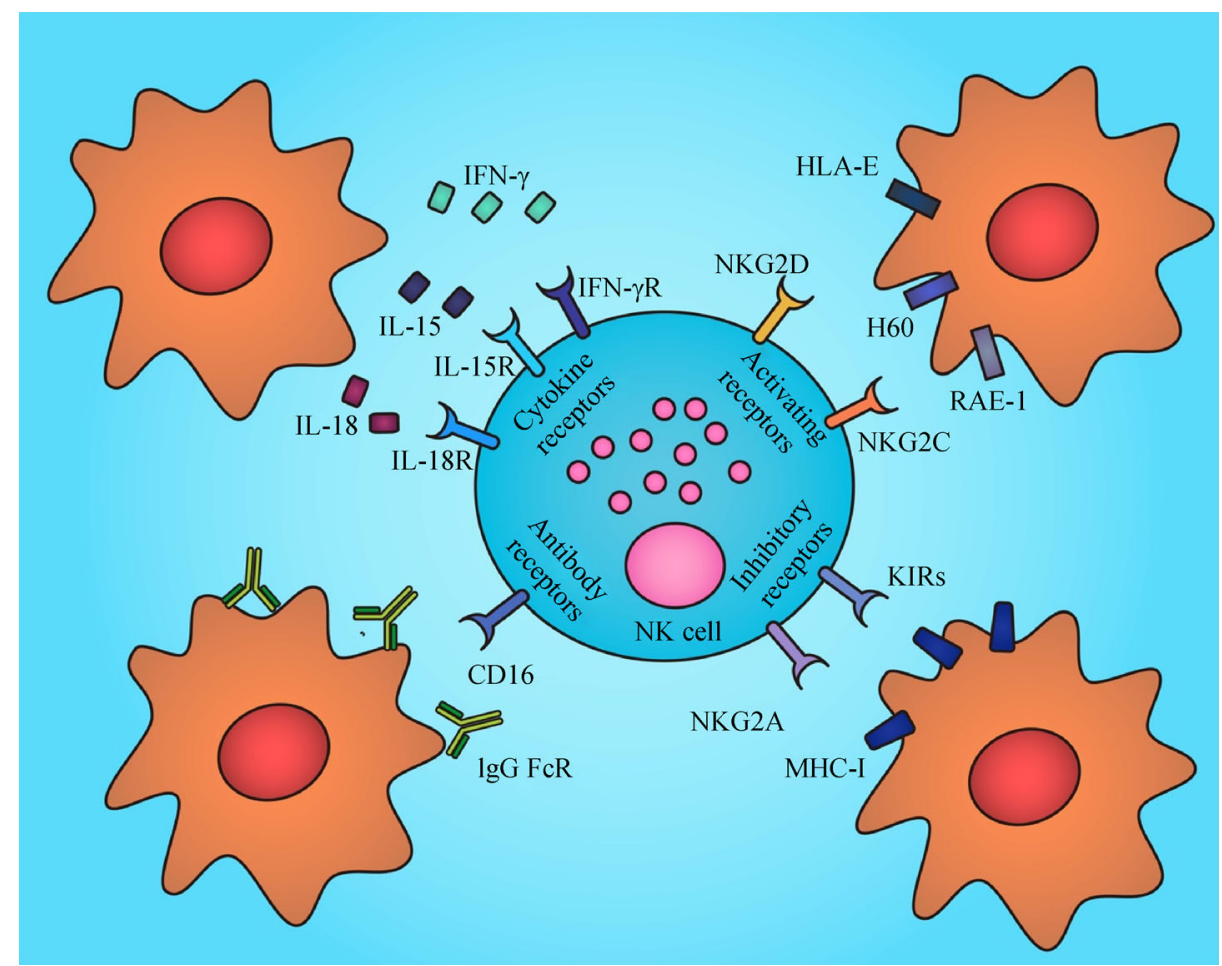

Fig. 2 NK cell surface receptors. NK cell surface receptors are broadly classified into four types: cytokine receptors, antibody receptors, activating receptors, and inhibitory receptors. When viral infection occurs, NK cells could be activated by cytokines, such as type I IFNs or IL-18 secreted by accessory cells. They could also be activated by antibody-coated cells that crosslink immunoglobulin G receptor CD16. KIRs and CD94/NKG2A are the major inhibitory receptors on NK cells. In addition, NK cells have activating receptors (e.g., NKG2D and $\mathrm{NKG} 2 \mathrm{C}$ ) expressed on their membrane that could initiate rapid killing of target cells.

\section{Intercellular innate immune signaling}

Intercellular communication and secretion of cytokines/ chemokines ensure fast and efficient responses to the threats from the environment surrounding the host cells. Besides the classical innate immune signaling, the transfer of PAMPs and host-derived signaling molecules from the infected host cells to the neighboring non-infected cells serves as an important alternative pathway. This process is an essential component in viral uptake, especially during the inhibition of innate immunity induced by persistent infection. It also helps the virus evade the host immune system through immunoregulatory mechanisms $[115,116]$. Intercellular communication mainly occurs through the cellular release of extracellular vesicles (EVs). Exosomes are a type of EVs ranging from $30 \mathrm{~nm}$ to $100 \mathrm{~nm}$ in diameter; they contain host (or pathogen)-derived nucleic acid, protein, and lipid cargos. These contents could be captured in the cytosol via endosomal membrane invagination and enriched by interacting with endosomal sorting complexes required for transport (ESCRTs) [117]. In the context of viral infections, exosomes containing viral mRNAs and microRNAs (miRNAs) could be released into extracellular spaces and detected in biological fluids, such as blood, cerebrospinal fluid, urine, semen, and breast milk. These exosomes mediate immune responses by regulating the production of type I IFNs in the surrounding uninfected cells and control the viral dissemination [118120].

$\mathrm{HCV}$ is an ssRNA virus. HCV-infected cells induce the production of type I IFNs of uninfected pDCs through a cell-to-cell RNA transfer mechanism rather than virusparticle assembly and virus-particle release [121]. A follow-up study showed that this process was mediated by the release of exosomes, which could be suppressed by exosome release inhibitors [122]. Therefore, exosomal RNA transfer is an important mechanism for the activation of innate immunity during infection.

Besides the PAMP exportation during infection, host PRR proteins can also be transferred via cell-to-cell interaction. The inflammasome is a cytoplasmic protein complex responding to pathogens and warning signals. It contains the innate immune sensor and the adaptor molecule apoptosis-associated speck-like protein containing a CARD (ASC), which generates a "speck" in the cytoplasm. Caspase-1 is then recruited to cleave and activate IL-1 $\beta$ and IL-18 $[123,124]$. The inflammasome complex can remain stable and last for up to $72 \mathrm{~h}$ in vitro 
[125]. If there is proIL-1 $\beta$ and proIL-18 available extracellularly, they will activate the inflammasome complex and induce inflammation [126,127]. Moreover, the infected and dying cells can transfer these signals, such as inactive substrates, to neighboring cells. It indicates that the pathogen is detected through the extracellular ASC specks phagocytosis followed by activation of an additional anti-microbial immune response by neighboring cells. However, some pathogens also destroy these mechanisms to benefit their survival and prolong their presence in host cells $[118,128]$ (Fig. 3). It is still unclear how far these intercellular communications can spread and how to control it. Nonetheless, this type of communication in the innate immune system may also provide potential therapeutic strategies for viral infectious diseases.

\section{Metabolic changes in innate immunity after viral invasion}

Viruses generally do not have their own metabolism as they are not living entities. They could induce alterations in cellular metabolism, such as increasing glycoproteins for the envelope of the virus, nucleotides for viral genome replication, and amino acid for virion assembly, to gain specific materials required for virion production. In addition, the altered cellular metabolism may improve the survival of infected cells aiding the persistence of the virus [129-133]. The altered core cellular metabolic pathways include glycolysis, fatty acid synthesis, and glutaminolysis. HCV infection in Huh7 cells increases glucose requirement and decreases host cell oxidative phosphorylation [134]. Increased expression of many glycolytic enzymes in Huh7 cells with HCV infection was shown in a global proteomic screen [131]. In addition, transcriptomic studies suggested that HCV microRNA miR-146a-5p could upregulate the transcription of genes related to fatty acid metabolism [135].

These alterations in host cells are mainly driven by IFNs to form an antiviral state and elicit subsequent immune responses. IFNs could affect the amino acid metabolism of cells by depleting polyamines and stimulating argininedependent nitric oxide (NO) production. Polyamine, which is generated from amino acid ornithine decarboxylation, consists of three molecules: putrescine, spermidine, and spermine [136]. It is associated with the process of deacetylation, transcription, and translation and affects cell proliferation, autophagy, and apoptosis. Putrescine is



Fig. 3 Intercellular transfer of virus-derived RNAs, microRNAs (miRNAs), and inflammasome complex leading to bystander activation of innate immunity. Virus-derived RNAs, including miRNAs, are produced in the infected cells and packaged into exosomes, which are released into the extracellular space. Then, the RNAs are internalized by the uninfected cells via endocytosis and activate TLRs and RIG-I to induce the production of type I IFN. Inflammasome activation could induce IL-1 $\beta$ and IL-18 production and pyroptosis, which is a type of cell death that causes inflammasome complex release and phagocytosis by neighboring cells to induce inflammasome activation. 
generated from ornithine, which is processed from Larginine by arginase [137]. Putrescine could also generate spermine. Type I IFN induces the spermidine-spermine acetyltransferase (SAT1) expression and decreases the expression levels of spermidine and spermine by acetylating them $[136,138]$. This reduction could inhibit RNA viral replication, as polyamines are essential for the transcription and translation of viral RNA and protein.

Moreover, IFNs stimulate the production of NO, which mediates the inhibition of viral replication and leads to enhanced clearance of the pathogen [139]. NO synthase (NOS) type 2 (iNOS) is induced by IFN- $\gamma$ and regulates the switch from L-arginine to L-citrulline to produce NO $[139,140]$. One of the antiviral activities of NO is the nitrosylation of viral molecules [141]. For instance, NO inhibits the activity of Coxsackievirus protease $3 \mathrm{C}$ by nitrosylating cysteine residue and disturbing the viral life cycle [142]. In addition, the NO generated by iNOS could deplete L-arginine and then reduce polyamines. Therefore, iNOS induced by IFN has antiviral effects through a shift from polyamine synthesis to NO production [143].

However, types I and II IFNs could also result in tissue damage due to the overproduction of reactive oxygen species and an increase in the apoptosis of overactivated immune cells [144-146]. In addition, large amounts of IFN-activated macrophages generate large amounts of NO, which also contributes to tissue damage [147]. In summary, the IFN-induced metabolic effects constitute one of the central antiviral mechanisms and suggest potential novel metabolic therapies for viral infectious diseases.

\section{Epigenetic changes in innate immunity after viral invasion}

Some viruses have developed several epigenetic strategies to replicate and survive in hosts, including taking advantage of pathogen-specific gene products to modify host proteins and chromatin, repressing PRR sensing and signaling pathways, and adjusting the expression of activators and repressors in innate immunity. Hosts also antagonize pathogen-induced changes in epigenomes to maintain an effective antipathogen immunity. Epigenetic regulation consists of DNA modifications, histone posttranslational modifications, chromatin remodeling, and non-coding RNAs. These epigenetic regulations involve the host and the virus.

Besides the epigenetic changes in innate immune signaling pathways and effector molecules driven by these main epigenetic regulators, pathogen-mediated epigenetic dysregulation to the host chromatin could help the virus with immune evasion, infection persistence, and inflammation [148]. Viruses mediating host chromatin modifier changes or encoding epigenetic regulators could cause the dysregulation of host chromatin in the infection. Respiratory syncytial virus (RSV) infection induces the upregulation of $\mathrm{H} 3 \mathrm{~K} 4$ demethylase KDM5B and represses type I interferons and the production of other innate cytokines [149]. The RNA viruses of the Flaviviridae family could change the m6A levels in host mRNAs [150]. These viruses use different mechanisms to alter the host's epigenome by targeting regulators for DNA and RNA methylations. Viruses could modify chromatin at a specific host gene locus. SETDB2, an H3K9me3 methyltransferase that triggers $\mathrm{H} 3 \mathrm{~K} 9 \mathrm{me} 3$ at gene promoters, could be induced by the influenza virus and inhibit neutrophil attractant CXC-chemokine ligand 1 and a subset of NF$\kappa \mathrm{B}$-inducible genes [151]. Moreover, the epigenetic dysregulation in immune-related diseases promotes viral infection. Airway diseases, such as asthma, upregulates TGF $\beta$ expression, which mediates the epigenetic reprogramming of lung epithelium known as epithelialto-mesenchymal transition. The transition induces the ZEB1 silencing of IRF1 expression, which leads to type III interferon silencing and enhanced RSV infections [152].

Chronic infection of some oncogenic viruses also interacts with epigenetic dysregulation to persist in the host and intensify infectious diseases and cancer pathogenesis. For instance, the microbial signals of chronic inflammation could induce pre-leukemic myeloproliferation in a host with TET2 mutations by inhibiting cytokine expression [153,154].

These chromatin modifiers affect the host and pathogen genes, which in turn affects the host's effective clearance and the pathogen's immune evasion. Thus, targeting these epigenetic modifiers represents potential novel therapies for viral infectious diseases.

\section{Conclusions and perspectives}

This review briefly discussed the role of the innate immune response in combating RNA viral infection and how several aspects of the innate cellular responses contribute to host protection. Different immune cells in the innate immune system have unique characteristics, and they utilize various mechanisms to eliminate viruses. This review did not focus on each aspect in depth but rather highlighted their commonality, differences, and interdependence. Clarifying the underlying mechanisms of how viruses evade innate immunity is considerably important for the understanding of viral pathogenesis and the preparation for the next emerging viral disease. Knowledge regarding mediators, such as signaling, metabolism, and epigenetics of the innate immune system, adds to the understanding of their contribution to innate immune responses and may lead to novel targets for the treatment of human viral infectious diseases. 


\section{Compliance with ethics guidelines}

Qian Xu, Yuting Tang, and Gang Huang declare no conflict of interest. This manuscript is a review article. It does not involve a research protocol requiring approval by relevant institutional review board or ethics committee.

Open Access This article is licensed under a Creative Commons Attribution 4.0 International License, which permits use, sharing, adaptation, distribution and reproduction in any medium or format, as long as you give appropriate credit to the original author(s) and the source, provide a link to the Creative Commons license, and indicate if changes were made.

The images or other third party material in this article are included in the article's Creative Commons license, unless indicated otherwise in a credit line to the material. If material is not included in the article's Creative Commons license and your intended use is not permitted by statutory regulation or exceeds the permitted use, you will need to obtain permission directly from the copyright holder.

To view a copy of this license, visit https://creativecommons.org/ licenses/by/4.0/.

\section{References}

1. Poltronieri P, Sun B, Mallardo M. RNA viruses: RNA roles in pathogenesis, coreplication and viral load. Curr Genomics 2015; 16(5): 327-335

2. Broz P, Monack DM. Newly described pattern recognition receptors team up against intracellular pathogens. Nat Rev Immunol 2013; 13(8): 551-565

3. Samuel CE. Antiviral actions of interferons. Clin Microbiol Rev 2001; 14(4): 778-809

4. Jensen S, Thomsen AR. Sensing of RNA viruses: a review of innate immune receptors involved in recognizing RNA virus invasion. J Virol 2012; 86(6): 2900-2910

5. Akira S, Takeda K. Toll-like receptor signalling. Nat Rev Immunol 2004; 4(7): 499-511

6. de Bouteiller O, Merck E, Hasan UA, Hubac S, Benguigui B, Trinchieri G, Bates EE, Caux C. Recognition of double-stranded RNA by human Toll-like receptor 3 and downstream receptor signaling requires multimerization and an acidic $\mathrm{pH}$. J Biol Chem 2005; 280(46): 38133-38145

7. Diebold SS, Kaisho T, Hemmi H, Akira S, Reis e Sousa C. Innate antiviral responses by means of TLR7-mediated recognition of single-stranded RNA. Science 2004; 303(5663): 1529-1531

8. Heil F, Hemmi H, Hochrein H, Ampenberger F, Kirschning C, Akira S, Lipford G, Wagner H, Bauer S. Species-specific recognition of single-stranded RNA via Toll-like receptor 7 and 8. Science 2004; 303(5663): 1526-1529

9. Takeuchi O, Akira S. Pattern recognition receptors and inflammation. Cell 2010; 140(6): 805-820

10. Krug A, French AR, Barchet W, Fischer JA, Dzionek A, Pingel JT, Orihuela MM, Akira S, Yokoyama WM, Colonna M. TLR9dependent recognition of MCMV by IPC and DC generates coordinated cytokine responses that activate antiviral NK cell function. Immunity 2004; 21(1): 107-119

11. Lai JH, Wang MY, Huang CY, Wu CH, Hung LF, Yang CY, Ke PY, Luo SF, Liu SJ, Ho LJ. Infection with the dengue RNA virus activates TLR9 signaling in human dendritic cells. EMBO Rep 2018; 19(8): 19

12. Yoneyama M, Fujita T. RNA recognition and signal transduction by RIG-I-like receptors. Immunol Rev 2009; 227(1): 54-65

13. Takahasi K, Yoneyama M, Nishihori T, Hirai R, Kumeta H, Narita R, Gale M Jr, Inagaki F, Fujita T. Nonself RNA-sensing mechanism of RIG-I helicase and activation of antiviral immune responses. Mol Cell 2008; 29(4): 428-440

14. Chiang JJ, Sparrer KMJ, van Gent M, Lässig C, Huang T, Osterrieder N, Hopfner KP, Gack MU. Viral unmasking of cellular 5S rRNA pseudogene transcripts induces RIG-I-mediated immunity. Nat Immunol 2018; 19(1): 53-62

15. Jiang M, Zhang S, Yang Z, Lin H, Zhu J, Liu L, Wang W, Liu S, Liu W, Ma Y, Zhang L, Cao X. Self-recognition of an inducible host lncRNA by RIG-I feedback restricts innate immune response. Cell 2018; 173: 906-919.e13

16. Zhao Y, Ye X, Dunker W, Song Y, Karijolich J. RIG-I like receptor sensing of host RNAs facilitates the cell-intrinsic immune response to KSHV infection. Nat Commun 2018; 9(1): 4841

17. Hou F, Sun L, Zheng H, Skaug B, Jiang QX, Chen ZJ. MAVS forms functional prion-like aggregates to activate and propagate antiviral innate immune response. Cell 2011; 146(3): 448-461

18. Son KN, Liang Z, Lipton HL. Double-stranded RNA is detected by immunofluorescence analysis in RNA and DNA virus infections, including those by negative-stranded RNA viruses. J Virol 2015; 89(18): 9383-9392

19. Sanchez David RY, Combredet C, Najburg V, Millot GA, Beauclair G, Schwikowski B, Léger T, Camadro JM, Jacob Y, Bellalou J, Jouvenet N, Tangy F, Komarova AV. LGP2 binds to PACT to regulate RIG-I- and MDA5-mediated antiviral responses. Sci Signal 2019; 12(601): eaar3993

20. Komuro A, Horvath CM. RNA- and virus-independent inhibition of antiviral signaling by RNA helicase LGP2. J Virol 2006; 80(24): 12332-12342

21. Saito T, Hirai R, Loo YM, Owen D, Johnson CL, Sinha SC, Akira S, Fujita T, Gale M Jr. Regulation of innate antiviral defenses through a shared repressor domain in RIG-I and LGP2. Proc Natl Acad Sci USA 2007; 104(2): 582-587

22. Brown GD, Willment JA, Whitehead L. C-type lectins in immunity and homeostasis. Nat Rev Immunol 2018; 18(6): 374-389

23. East L, Isacke CM. The mannose receptor family. Biochim Biophys Acta 2002; 1572(2-3): 364-386

24. Miller JL, de Wet BJ, Martinez-Pomares L, Radcliffe CM, Dwek RA, Rudd PM, Gordon S. The mannose receptor mediates dengue virus infection of macrophages. PLoS Pathog 2008; 4(2): e17

25. Gürtler C, Bowie AG. Innate immune detection of microbial nucleic acids. Trends Microbiol 2013; 21(8): 413-420

26. Carpenter S, Ricci EP, Mercier BC, Moore MJ, Fitzgerald KA. Post-transcriptional regulation of gene expression in innate immunity. Nat Rev Immunol 2014; 14(6): 361-376

27. Cao X. Self-regulation and cross-regulation of pattern-recognition receptor signalling in health and disease. Nat Rev Immunol 2016; 16(1): $35-50$ 
28. Tong AJ, Liu X, Thomas BJ, Lissner MM, Baker MR, Senagolage MD, Allred AL, Barish GD, Smale ST. A stringent systems approach uncovers gene-specific mechanisms regulating inflammation. Cell 2016; 165(1): 165-179

29. Honda K, Taniguchi T. IRFs: master regulators of signalling by Toll-like receptors and cytosolic pattern-recognition receptors. Nat Rev Immunol 2006; 6(9): 644-658

30. Högner K, Wolff T, Pleschka S, Plog S, Gruber AD, Kalinke U, Walmrath HD, Bodner J, Gattenlöhner S, Lewe-Schlosser P, Matrosovich M, Seeger W, Lohmeyer J, Herold S. Macrophageexpressed IFN- $\beta$ contributes to apoptotic alveolar epithelial cell injury in severe influenza virus pneumonia. PLoS Pathog 2013; 9 (2): e1003188

31. Kallfass C, Lienenklaus S, Weiss S, Staeheli P. Visualizing the $\beta$ interferon response in mice during infection with influenza A viruses expressing or lacking nonstructural protein 1. J Virol 2013; 87(12): 6925-6930

32. Jewell NA, Vaghefi N, Mertz SE, Akter P, Peebles RS Jr, Bakaletz LO, Durbin RK, Flaño E, Durbin JE. Differential type I interferon induction by respiratory syncytial virus and influenza a virus in vivo. J Virol 2007; 81(18): 9790-9800

33. Pothlichet J, Meunier I, Davis BK, Ting JP, Skamene E, von Messling V, Vidal SM. Type I IFN triggers RIG-I/TLR3/NLRP3dependent inflammasome activation in influenza A virus infected cells. PLoS Pathog 2013; 9(4): e1003256

34. Allen IC, Scull MA, Moore CB, Holl EK, McElvania-TeKippe E, Taxman DJ, Guthrie EH, Pickles RJ, Ting JP. The NLRP3 inflammasome mediates in vivo innate immunity to influenza A virus through recognition of viral RNA. Immunity 2009; 30(4): 556-565

35. Man SM, Kanneganti TD. Converging roles of caspases in inflammasome activation, cell death and innate immunity. Nat Rev Immunol 2016; 16(1): 7-21

36. von Moltke J, Ayres JS, Kofoed EM, Chavarría-Smith J, Vance RE. Recognition of bacteria by inflammasomes. Annu Rev Immunol 2013; 31(1): 73-106

37. Shi CS, Nabar NR, Huang NN, Kehrl JH. SARS-coronavirus open reading frame- $8 \mathrm{~b}$ triggers intracellular stress pathways and activates NLRP3 inflammasomes. Cell Death Discov 2019; 5(1): 101

38. Wong HH, Fung TS, Fang S, Huang M, Le MT, Liu DX. Accessory proteins $8 \mathrm{~b}$ and $8 \mathrm{ab}$ of severe acute respiratory syndrome coronavirus suppress the interferon signaling pathway by mediating ubiquitin-dependent rapid degradation of interferon regulatory factor 3. Virology 2018; 515: 165-175

39. Sun L, Wu J, Du F, Chen X, Chen ZJ. Cyclic GMP-AMP synthase is a cytosolic DNA sensor that activates the type I interferon pathway. Science 2013; 339(6121): 786-791

40. Wu J, Sun L, Chen X, Du F, Shi H, Chen C, Chen ZJ. Cyclic GMPAMP is an endogenous second messenger in innate immune signaling by cytosolic DNA. Science 2013; 339(6121): 826-830

41. Zheng Y, Liu Q, Wu Y, Ma L, Zhang Z, Liu T, Jin S, She Y, Li YP, Cui J. Zika virus elicits inflammation to evade antiviral response by cleaving cGAS via NS1-caspase-1 axis. EMBO J 2018; 37(18): e99347

42. Farhat K, Riekenberg S, Heine H, Debarry J, Lang R, Mages J, Buwitt-Beckmann U, Röschmann K, Jung G, Wiesmüller KH,
Ulmer AJ. Heterodimerization of TLR2 with TLR1 or TLR6 expands the ligand spectrum but does not lead to differential signaling. J Leukoc Biol 2008; 83(3): 692-701

43. Jin MS, Kim SE, Heo JY, Lee ME, Kim HM, Paik SG, Lee H, Lee JO. Crystal structure of the TLR1-TLR2 heterodimer induced by binding of a tri-acylated lipopeptide. Cell 2007; 130(6): 10711082

44. Hoshino K, Takeuchi O, Kawai T, Sanjo H, Ogawa T, Takeda Y, Takeda K, Akira S. Cutting edge: Toll-like receptor 4 (TLR4)deficient mice are hyporesponsive to lipopolysaccharide: evidence for TLR4 as the Lps gene product. J Immunol 1999; 162(7): 3749 3752

45. Schwandner R, Dziarski R, Wesche H, Rothe M, Kirschning CJ. Peptidoglycan- and lipoteichoic acid-induced cell activation is mediated by toll-like receptor 2. J Biol Chem 1999; 274(25): 17406-17409

46. Hayashi F, Smith KD, Ozinsky A, Hawn TR, Yi EC, Goodlett DR, Eng JK, Akira S, Underhill DM, Aderem A. The innate immune response to bacterial flagellin is mediated by Toll-like receptor 5 . Nature 2001; 410(6832): 1099-1103

47. Place DE, Kanneganti TD. Recent advances in inflammasome biology. Curr Opin Immunol 2018; 50: 32-38

48. Martinez FO, Gordon S. The evolution of our understanding of macrophages and translation of findings toward the clinic. Expert Rev Clin Immunol 2015; 11(1): 5-13

49. de Las Casas-Engel M, Corbí AL. Serotonin modulation of macrophage polarization: inflammation and beyond. Adv Exp Med Biol 2014; 824: 89-115

50. Ginhoux F, Jung S. Monocytes and macrophages: developmental pathways and tissue homeostasis. Nat Rev Immunol 2014; 14(6): 392-404

51. Xue J, Schmidt SV, Sander J, Draffehn A, Krebs W, Quester I, De Nardo D, Gohel TD, Emde M, Schmidleithner L, Ganesan H, Nino-Castro A, Mallmann MR, Labzin L, Theis H, Kraut M, Beyer M, Latz E, Freeman TC, Ulas T, Schultze JL. Transcriptome-based network analysis reveals a spectrum model of human macrophage activation. Immunity 2014; 40(2): 274-288

52. Murray PJ, Allen JE, Biswas SK, Fisher EA, Gilroy DW, Goerdt S, Gordon S, Hamilton JA, Ivashkiv LB, Lawrence T, Locati M, Mantovani A, Martinez FO, Mege JL, Mosser DM, Natoli G, Saeij JP, Schultze JL, Shirey KA, Sica A, Suttles J, Udalova I, van Ginderachter JA, Vogel SN, Wynn TA. Macrophage activation and polarization: nomenclature and experimental guidelines. Immunity 2014; 41(1): 14-20

53. Domínguez-Soto A, de las Casas-Engel M, Bragado R, MedinaEcheverz J, Aragoneses-Fenoll L, Martín-Gayo E, van Rooijen N, Berraondo P, Toribio ML, Moro MA, Cuartero I, Castrillo A, Sancho D, Sánchez-Torres C, Bruhns P, Sánchez-Ramón S, Corbí $\mathrm{AL}$. Intravenous immunoglobulin promotes antitumor responses by modulating macrophage polarization. J Immunol 2014; 193 (10): 5181-5189

54. Martinez FO, Gordon S. The M1 and M2 paradigm of macrophage activation: time for reassessment. F1000Prime Rep 2014; 6: 13

55. Gad HH, Dellgren C, Hamming OJ, Vends S, Paludan SR, Hartmann R. Interferon- $\lambda$ is functionally an interferon but structurally related to the interleukin-10 family. J Biol Chem 2009; 284(31): 20869-20875 
56. Sang Y, Brichalli W, Rowland RR, Blecha F. Genome-wide analysis of antiviral signature genes in porcine macrophages at different activation statuses. PLoS One 2014; 9(2): e87613

57. Schindler C, Levy DE, Decker T. JAK-STAT signaling: from interferons to cytokines. J Biol Chem 2007; 282(28): 20059-20063

58. McNab F, Mayer-Barber K, Sher A, Wack A, O’Garra A. Type I interferons in infectious disease. Nat Rev Immunol 2015; 15(2): 87-103 doi: $10.1038 /$ nri3787

59 . Koch S, Finotto S. Role of interferon- $\lambda$ in allergic asthma. J Innate Immun 2015; 7(3): 224-230

60. Ivashkiv LB, Donlin LT. Regulation of type I interferon responses. Nat Rev Immunol 2014; 14(1): 36-49

61. Zhao X, Dai J, Xiao X, Wu L, Zeng J, Sheng J, Su J, Chen X, Wang G, Li K. PI3K/Akt signaling pathway modulates influenza virus induced mouse alveolar macrophage polarization to M1/M2b. PLoS One 2014; 9(8): e104506

62. Yang Y, Zhang R, Xia F, Zou T, Huang A, Xiong S, Zhang J. LPS converts $\mathrm{Gr}-1^{+} \mathrm{CD} 115^{+}$myeloid-derived suppressor cells from M2 to M1 via P38 MAPK. Exp Cell Res 2013; 319(12): 17741783

63. González-Navajas JM, Lee J, David M, Raz E. Immunomodulatory functions of type I interferons. Nat Rev Immunol 2012; 12(2): $125-135$

64. Jaume M, Yip MS, Cheung CY, Leung HL, Li PH, Kien F, Dutry I, Callendret B, Escriou N, Altmeyer R, Nal B, Daëron M, Bruzzone $\mathrm{R}$, Peiris JS. Anti-severe acute respiratory syndrome coronavirus spike antibodies trigger infection of human immune cells via a $\mathrm{pH}-$ and cysteine protease-independent Fc $\gamma \mathrm{R}$ pathway. J Virol 2011; 85 (20): 10582-10597

65. Yip MS, Leung NH, Cheung CY, Li PH, Lee HH, Daëron M, Peiris JS, Bruzzone R, Jaume M. Antibody-dependent infection of human macrophages by severe acute respiratory syndrome coronavirus. Virol J 2014; 11(1): 82

66. Zhao J, Zhao J, Van Rooijen N, Perlman S. Evasion by stealth: inefficient immune activation underlies poor $\mathrm{T}$ cell response and severe disease in SARS-CoV-infected mice. PLoS Pathog 2009; 5 (10): e 1000636

67. Tatano Y, Shimizu T, Tomioka H. Unique macrophages different from M1/M2 macrophages inhibit $\mathrm{T}$ cell mitogenesis while upregulating Th17 polarization. Sci Rep 2014; 4(1): 4146

68. Darwish I, Mubareka S, Liles WC. Immunomodulatory therapy for severe influenza. Expert Rev Anti Infect Ther 2011; 9(7): 807-822

69. Boehler RM, Kuo R, Shin S, Goodman AG, Pilecki MA, Gower $\mathrm{RM}$, Leonard JN, Shea LD. Lentivirus delivery of IL-10 to promote and sustain macrophage polarization towards an antiinflammatory phenotype. Biotechnol Bioeng 2014; 111(6): 12101221

70. Richter K, Perriard G, Behrendt R, Schwendener RA, Sexl V, Dunn R, Kamanaka M, Flavell RA, Roers A, Oxenius A. Macrophage and T cell produced IL-10 promotes viral chronicity. PLoS Pathog 2013; 9(11): e1003735

71. Zdrenghea MT, Makrinioti H, Muresan A, Johnston SL, Stanciu LA. The role of macrophage IL-10/innate IFN interplay during virus-induced asthma. Rev Med Virol 2015; 25(1): 33-49

72. Ouyang P, Rakus K, van Beurden SJ, Westphal AH, Davison AJ, Gatherer D, Vanderplasschen AF. IL-10 encoded by viruses: a remarkable example of independent acquisition of a cellular gene by viruses and its subsequent evolution in the viral genome. J Gen Virol 2014; 95(Pt 2): 245-262

73. Wilson EB, Brooks DG. The role of IL-10 in regulating immunity to persistent viral infections. Curr Top Microbiol Immunol 2011; 350: $39-65$

74. Perkins DJ, Polumuri SK, Pennini ME, Lai W, Xie P, Vogel SN. Reprogramming of murine macrophages through TLR2 confers viral resistance via TRAF3-mediated, enhanced interferon production. PLoS Pathog 2013; 9(7): e1003479

75. Patel MC, Shirey KA, Pletneva LM, Boukhvalova MS, GarzinoDemo A, Vogel SN, Blanco JC. Novel drugs targeting Toll-like receptors for antiviral therapy. Future Virol 2014; 9(9): 811-829

76. Zhang B, Chassaing B, Shi Z, Uchiyama R, Zhang Z, Denning TL, Crawford SE, Pruijssers AJ, Iskarpatyoti JA, Estes MK, Dermody TS, Ouyang W, Williams IR, Vijay-Kumar M, Gewirtz AT. Prevention and cure of rotavirus infection via TLR5/NLRC4mediated production of IL-22 and IL-18. Science 2014; 346(6211): 861-865

77. Liu K, Nussenzweig MC. Origin and development of dendritic cells. Immunol Rev 2010; 234(1): 45-54

78. Pulendran B, Palucka K, Banchereau J. Sensing pathogens and tuning immune responses. Science 2001; 293(5528): 253-256

79. Collin M, McGovern N, Haniffa M. Human dendritic cell subsets. Immunology 2013; 140(1): 22-30

80. Ziegler-Heitbrock L, Ancuta P, Crowe S, Dalod M, Grau V, Hart DN, Leenen PJ, Liu YJ, MacPherson G, Randolph GJ, Scherberich J, Schmitz J, Shortman K, Sozzani S, Strobl H, Zembala M, Austyn JM, Lutz MB. Nomenclature of monocytes and dendritic cells in blood. Blood 2010; 116(16): e74-e80

81. Moretta A. Natural killer cells and dendritic cells: rendezvous in abused tissues. Nat Rev Immunol 2002; 2(12): 957-964

82. Swiecki M, Colonna M. The multifaceted biology of plasmacytoid dendritic cells. Nat Rev Immunol 2015; 15(8): 471-485

83. Webster B, Assil S, Dreux M. Cell-cell sensing of viral infection by plasmacytoid dendritic cells. J Virol 2016; 90(22): 10050-10053

84. Dessouki O, Kamiya Y, Nagahama H, Tanaka M, Suzu S, Sasaki Y, Okada S. Chronic hepatitis C viral infection reduces NK cell frequency and suppresses cytokine secretion: reversion by antiviral treatment. Biochem Biophys Res Commun 2010; 393(2): 331-337

85. Jinushi M, Takehara T, Tatsumi T, Kanto T, Groh V, Spies T, Suzuki T, Miyagi T, Hayashi N. Autocrine/paracrine IL-15 that is required for type I IFN-mediated dendritic cell expression of MHC class I-related chain A and B is impaired in hepatitis $\mathrm{C}$ virus infection. J Immunol 2003; 171(10): 5423-5429

86. Kiessling R, Klein E, Wigzell H. "Natural" killer cells in the mouse. I. Cytotoxic cells with specificity for mouse Moloney leukemia cells. Specificity and distribution according to genotype. Eur J Immunol 1975; 5(2): 112-117

87. Hammer Q, Rückert T, Romagnani C. Natural killer cell specificity for viral infections. Nat Immunol 2018; 19(8): 800-808

88. Kronstad LM, Seiler C, Vergara R, Holmes SP, Blish CA. Differential induction of IFN- $\alpha$ and modulation of CD112 and CD54 expression govern the magnitude of NK cell IFN $-\gamma$ response to influenza A viruses. J Immunol 2018; 201(7): 2117-2131

89. Martín-Fontecha A, Thomsen LL, Brett S, Gerard C, Lipp M, Lanzavecchia A, Sallusto F. Induced recruitment of NK cells to 
lymph nodes provides IFN- $\gamma$ for $\mathrm{T}(\mathrm{H}) 1$ priming. Nat Immunol 2004; 5(12): 1260-1265

90. Wagstaffe HR, Nielsen CM, Riley EM, Goodier MR. IL-15 promotes polyfunctional NK cell responses to influenza by boosting IL-12 production. J Immunol 2018; 200(8): 2738-2747

91. Zamora AE, Aguilar EG, Sungur CM, Khuat LT, Dunai C, Lochhead GR, Du J, Pomeroy C, Blazar BR, Longo DL, Venstrom JM, Baumgarth N, Murphy WJ. Licensing delineates helper and effector NK cell subsets during viral infection. JCI Insight 2017; 2 (10): e87032

92. Vivier E, Tomasello E, Baratin M, Walzer T, Ugolini S. Functions of natural killer cells. Nat Immunol 2008; 9(5): 503-510

93. Liu LL, Landskron J, Ask EH, Enqvist M, Sohlberg E, Traherne JA, Hammer Q, Goodridge JP, Larsson S, Jayaraman J, Oei VYS, Schaffer M, Taskén K, Ljunggren HG, Romagnani C, Trowsdale J, Malmberg KJ, Béziat V. Critical role of CD2 co-stimulation in adaptive natural killer cell responses revealed in NKG2C-deficient humans. Cell Reports 2016; 15(5): 1088-1099

94. Luetke-Eversloh M, Hammer Q, Durek P, Nordström K, Gasparoni G, Pink M, Hamann A, Walter J, Chang HD, Dong J, Romagnani C. Human cytomegalovirus drives epigenetic imprinting of the IFNG locus in NKG2Chi natural killer cells. PLoS Pathog 2014; 10(10): e1004441

95. Nguyen KB, Salazar-Mather TP, Dalod MY, Van Deusen JB, Wei XQ, Liew FY, Caligiuri MA, Durbin JE, Biron CA. Coordinated and distinct roles for IFN- $\alpha \beta$, IL-12, and IL-15 regulation of NK cell responses to viral infection. J Immunol 2002; 169(8): 42794287

96. Madera S, Rapp M, Firth MA, Beilke JN, Lanier LL, Sun JC. Type I IFN promotes NK cell expansion during viral infection by protecting NK cells against fratricide. J Exp Med 2016; 213(2): 225-233

97. Strauss-Albee DM, Fukuyama J, Liang EC, Yao Y, Jarrell JA, Drake AL, Kinuthia J, Montgomery RR, John-Stewart G, Holmes S, Blish CA. Human NK cell repertoire diversity reflects immune experience and correlates with viral susceptibility. Sci Transl Med 2015; 7(297): 297ra115

98. Kärre K. Natural killer cell recognition of missing self. Nat Immunol 2008; 9(5): 477-480

99. Glienke J, Sobanov Y, Brostjan C, Steffens C, Nguyen C, Lehrach $\mathrm{H}$, Hofer E, Francis F. The genomic organization of NKG2C, E, F, and $\mathrm{D}$ receptor genes in the human natural killer gene complex. Immunogenetics 1998; 48(3): 163-173

100. Hatjiharissi E, Xu L, Santos DD, Hunter ZR, Ciccarelli BT, Verselis S, Modica M, Cao Y, Manning RJ, Leleu X, Dimmock EA, Kortsaris A, Mitsiades C, Anderson KC, Fox EA, Treon SP. Increased natural killer cell expression of CD16, augmented binding and ADCC activity to rituximab among individuals expressing the Fc $\gamma$ RIIIa-158 V/V and V/F polymorphism. Blood 2007; 110(7): 2561-2564

101. Sivori S, Parolini S, Marcenaro E, Millo R, Bottino C, Moretta A. Triggering receptors involved in natural killer cell-mediated cytotoxicity against choriocarcinoma cell lines. Hum Immunol 2000; 61(11): 1055-1058

102. Hsu HT, Mace EM, Carisey AF, Viswanath DI, Christakou AE, Wiklund M, Önfelt B, Orange JS. NK cells converge lytic granules to promote cytotoxicity and prevent bystander killing. J Cell Biol
2016; 215(6): 875-889

103. Mace EM, Orange JS. Genetic causes of human NK cell deficiency and their effect on NK cell subsets. Front Immunol 2016; 7: 545

104. Wong E, Xu RH, Rubio D, Lev A, Stotesbury C, Fang M, Sigal LJ. Migratory dendritic cells, group 1 innate lymphoid cells, and inflammatory monocytes collaborate to recruit NK cells to the virus-infected lymph node. Cell Reports 2018; 24(1): 142-154

105. Lanier LL. Evolutionary struggles between NK cells and viruses. Nat Rev Immunol 2008; 8(4): 259-268

106. Raulet DH, Gasser S, Gowen BG, Deng W, Jung H. Regulation of ligands for the NKG2D activating receptor. Annu Rev Immunol 2013; 31(1): 413-441

107. McQuaid S, Loughran S, Power P, Maguire P, Walls D, Cusi MG, Orvell C, Johnson P. Haemagglutinin-neuraminidase from HPIV3 mediates human NK regulation of T cell proliferation via NKp44 and NKp46. J Gen Virol 2018; 99(6): 763-767

108. Mendelson M, Tekoah Y, Zilka A, Gershoni-Yahalom O, Gazit R, Achdout H, Bovin NV, Meningher T, Mandelboim M, Mandelboim O, David A, Porgador A. NKp46 O-glycan sequences that are involved in the interaction with hemagglutinin type 1 of influenza virus. J Virol 2010; 84(8): 3789-3797

109. Diab M, Glasner A, Isaacson B, Bar-On Y, Drori Y, Yamin R, Duev-Cohen A, Danziger O, Zamostiano R, Mandelboim M, Jonjic S, Bacharach E, Mandelboim O. NK-cell receptors NKp46 and NCR1 control human metapneumovirus infection. Eur J Immunol 2017; 47(4): 692-703

110. Bar-On Y, Charpak-Amikam Y, Glasner A, Isaacson B, DuevCohen A, Tsukerman P, Varvak A, Mandelboim M, Mandelboim O. NKp46 recognizes the sigma1 protein of reovirus: implications for reovirus-based cancer therapy. J Virol 2017; 91(19): e01045-17

111. Ahlenstiel G, Titerence RH, Koh C, Edlich B, Feld JJ, Rotman Y, Ghany MG, Hoofnagle JH, Liang TJ, Heller T, Rehermann B. Natural killer cells are polarized toward cytotoxicity in chronic hepatitis $\mathrm{C}$ in an interferon- $\alpha$-dependent manner. Gastroenterology 2010; 138: 325-335.e1-2

112. Béziat V, Dalgard O, Asselah T, Halfon P, Bedossa P, Boudifa A, Hervier B, Theodorou I, Martinot M, Debré P, Björkström NK, Malmberg KJ, Marcellin P, Vieillard V. CMV drives clonal expansion of $\mathrm{NKG}_{2} \mathrm{C}^{+} \mathrm{NK}$ cells expressing self-specific KIRs in chronic hepatitis patients. Eur J Immunol 2012; 42(2): 447-457

113. Malone DFG, Lunemann S, Hengst J, Ljunggren HG, Manns MP, Sandberg JK, Cornberg M, Wedemeyer H, Björkström NK. Cytomegalovirus-driven adaptive-like natural killer cell expansions are unaffected by concurrent chronic hepatitis virus infections. Front Immunol 2017; 8: 525

114. Petitdemange C, Wauquier N, Devilliers H, Yssel H, Mombo I, Caron M, Nkoghé D, Debré P, Leroy E, Vieillard V. Longitudinal analysis of natural killer cells in dengue virus-infected patients in comparison to Chikungunya and Chikungunya/Dengue virusinfected patients. PLoS Negl Trop Dis 2016; 10(3): e0004499

115. Mittelbrunn M, Gutiérrez-Vázquez C, Villarroya-Beltri C, González S, Sánchez-Cabo F, González MA, Bernad A, Sánchez-Madrid F. Unidirectional transfer of microRNA-loaded exosomes from $\mathrm{T}$ cells to antigen-presenting cells. Nat Commun 2011; 2(1): 282

116. Schorey JS, Harding CV. Extracellular vesicles and infectious diseases: new complexity to an old story. J Clin Invest 2016; 126 (4): $1181-1189$ 
117. Tamai K, Tanaka N, Nakano T, Kakazu E, Kondo Y, Inoue J, Shiina M, Fukushima K, Hoshino T, Sano K, Ueno Y, Shimosegawa T, Sugamura K. Exosome secretion of dendritic cells is regulated by Hrs, an ESCRT-0 protein. Biochem Biophys Res Commun 2010; 399(3): 384-390

118. Kalamvoki M, Deschamps T. Extracellular vesicles during herpes simplex virus type 1 infection: an inquire. Virol J 2016; 13(1): 63

119. Ratajczak MZ, Ratajczak J. Horizontal transfer of RNA and proteins between cells by extracellular microvesicles: 14 years later. Clin Transl Med 2016; 5(1): 7

120. Schwab A, Meyering SS, Lepene B, Iordanskiy S, van Hoek ML, Hakami RM, Kashanchi F. Extracellular vesicles from infected cells: potential for direct pathogenesis. Front Microbiol 2015; 6: 1132

121. Takahashi K, Asabe S, Wieland S, Garaigorta U, Gastaminza P, Isogawa M, Chisari FV. Plasmacytoid dendritic cells sense hepatitis C virus-infected cells, produce interferon, and inhibit infection. Proc Natl Acad Sci USA 2010; 107(16): 7431-7436

122. Dreux M, Garaigorta U, Boyd B, Décembre E, Chung J, WhittenBauer C, Wieland S, Chisari FV. Short-range exosomal transfer of viral RNA from infected cells to plasmacytoid dendritic cells triggers innate immunity. Cell Host Microbe 2012; 12(4): 558-570

123. Liu X, Zhang Z, Ruan J, Pan Y, Magupalli VG, Wu H, Lieberman J. Inflammasome-activated gasdermin $\mathrm{D}$ causes pyroptosis by forming membrane pores. Nature 2016; 535(7610): 153-158

124. Lu A, Magupalli VG, Ruan J, Yin Q, Atianand MK, Vos MR, Schröder GF, Fitzgerald KA, Wu H, Egelman EH. Unified polymerization mechanism for the assembly of ASC-dependent inflammasomes. Cell 2014; 156(6): 1193-1206

125. Balci-Peynircioglu B, Waite AL, Schaner P, Taskiran ZE, Richards N, Orhan D, Gucer S, Ozen S, Gumucio D, Yilmaz E. Expression of ASC in renal tissues of familial mediterranean fever patients with amyloidosis: postulating a role for ASC in AA type amyloid deposition. Exp Biol Med (Maywood) 2008; 233(11): 1324-1333

126. Baroja-Mazo A, Martín-Sánchez F, Gomez AI, Martínez CM, Amores-Iniesta J, Compan V, Barberà-Cremades M, Yagüe J, Ruiz-Ortiz E, Antón J, Buján S, Couillin I, Brough D, Arostegui JI, Pelegrín P. The NLRP3 inflammasome is released as a particulate danger signal that amplifies the inflammatory response. Nat Immunol 2014; 15(8): 738-748

127. Franklin BS, Bossaller L, De Nardo D, Ratter JM, Stutz A, Engels G, Brenker C, Nordhoff M, Mirandola SR, Al-Amoudi A, Mangan MS, Zimmer S, Monks BG, Fricke M, Schmidt RE, Espevik T, Jones B, Jarnicki AG, Hansbro PM, Busto P, Marshak-Rothstein A, Hornemann S, Aguzzi A, Kastenmüller W, Latz E. The adaptor ASC has extracellular and 'prionoid' activities that propagate inflammation. Nat Immunol 2014; 15(8): 727-737

128. Chahar HS, Bao X, Casola A. Exosomes and their role in the life cycle and pathogenesis of RNA viruses. Viruses 2015; 7(6): 32043225

129. Birungi G, Chen SM, Loy BP, Ng ML, Li SF. Metabolomics approach for investigation of effects of dengue virus infection using the EA.hy926 cell line. J Proteome Res 2010; 9(12): 65236534

130. Delgado T, Sanchez EL, Camarda R, Lagunoff M. Global metabolic profiling of infection by an oncogenic virus: KSHV induces and requires lipogenesis for survival of latent infection.
PLoS Pathog 2012; 8(8): e1002866

131. Diamond DL, Syder AJ, Jacobs JM, Sorensen CM, Walters KA, Proll SC, McDermott JE, Gritsenko MA, Zhang Q, Zhao R, Metz TO, Camp DG 2nd, Waters KM, Smith RD, Rice CM, Katze MG. Temporal proteome and lipidome profiles reveal hepatitis $\mathrm{C}$ virusassociated reprogramming of hepatocellular metabolism and bioenergetics. PLoS Pathog 2010; 6(1): e1000719

132. Fontaine KA, Camarda R, Lagunoff M. Vaccinia virus requires glutamine but not glucose for efficient replication. J Virol 2014; 88 (8): 4366-4374

133. Fontaine KA, Sanchez EL, Camarda R, Lagunoff M. Dengue virus induces and requires glycolysis for optimal replication. J Virol 2015; 89(4): 2358-2366

134. Ramière C, Rodriguez J, Enache LS, Lotteau V, André P, Diaz O. Activity of hexokinase is increased by its interaction with hepatitis C virus protein NS5A. J Virol 2014; 88(6): 3246-3254

135. Bandiera S, Pernot S, El Saghire H, Durand SC, Thumann C, Crouchet E, Ye T, Fofana I, Oudot MA, Barths J, Schuster C, Pessaux P, Heim MH, Baumert TF, Zeisel MB. Hepatitis C virusinduced upregulation of microRNA miR-146a-5p in hepatocytes promotes viral infection and deregulates metabolic pathways associated with liver disease pathogenesis. J Virol 2016; 90(14): 6387-6400

136. Ramani D, De Bandt JP, Cynober L. Aliphatic polyamines in physiology and diseases. Clin Nutr 2014; 33(1): 14-22

137. Minois N, Carmona-Gutierrez D, Madeo F. Polyamines in aging and disease. Aging (Albany NY) 2011; 3(8): 716-732

138. Mounce BC, Poirier EZ, Passoni G, Simon-Loriere E, Cesaro T, Prot M, Stapleford KA, Moratorio G, Sakuntabhai A, Levraud JP, Vignuzzi M. Interferon-induced spermidine-spermine acetyltransferase and polyamine depletion restrict Zika and Chikungunya viruses. Cell Host Microbe 2016; 20(2): 167-177

139. Reiss CS, Komatsu T. Does nitric oxide play a critical role in viral infections? J Virol 1998; 72(6): 4547-4551

140. Uehara EU, Shida BS, de Brito CA. Role of nitric oxide in immune responses against viruses: beyond microbicidal activity. Inflamm Res 2015; 64(11): 845-852

141. Colasanti M, Persichini T, Venturini G, Ascenzi P. S-nitrosylation of viral proteins: molecular bases for antiviral effect of nitric oxide. IUBMB Life 1999; 48(1): 25-31

142. Saura M, Zaragoza C, McMillan A, Quick RA, Hohenadl C, Lowenstein JM, Lowenstein CJ. An antiviral mechanism of nitric oxide: inhibition of a viral protease. Immunity 1999; 10(1): 21-28

143. Hu J, Mahmoud MI, el-Fakahany EE. Polyamines inhibit nitric oxide synthase in rat cerebellum. Neurosci Lett 1994; 175(1-2): $41-45$

144. Dorhoi A, Yeremeev V, Nouailles G, Weiner J 3rd, Jörg S, Heinemann E, Oberbeck-Müller D, Knaul JK, Vogelzang A, Reece ST, Hahnke K, Mollenkopf HJ, Brinkmann V, Kaufmann SH. Type I IFN signaling triggers immunopathology in tuberculosissusceptible mice by modulating lung phagocyte dynamics. Eur J Immunol 2014; 44(8): 2380-2393

145. Watanabe Y, Suzuki O, Haruyama T, Akaike T. Interferon- $\gamma$ induces reactive oxygen species and endoplasmic reticulum stress at the hepatic apoptosis. J Cell Biochem 2003; 89(2): 244-253

146. Yim HY, Yang Y, Lim JS, Lee MS, Zhang DE, Kim KI. The mitochondrial pathway and reactive oxygen species are critical 
contributors to interferon- $\alpha / \beta$-mediated apoptosis in Ubp43deficient hematopoietic cells. Biochem Biophys Res Commun 2012; 423(2): 436-440

147. Burrack KS, Morrison TE. The role of myeloid cell activation and arginine metabolism in the pathogenesis of virus-induced diseases. Front Immunol 2014; 5: 428

148. Paschos K, Allday MJ. Epigenetic reprogramming of host genes in viral and microbial pathogenesis. Trends Microbiol 2010; 18(10): 439-447

149. Ptaschinski C, Mukherjee S, Moore ML, Albert M, Helin K, Kunkel SL, Lukacs NW. RSV-induced H3K4 demethylase KDM5B leads to regulation of dendritic cell-derived innate cytokines and exacerbates pathogenesis in vivo. PLoS Pathog 2015; 11(6): e1004978

150. Gokhale NS, Horner SM. RNA modifications go viral. PLoS Pathog 2017; 13(3): e1006188

151. Schliehe C, Flynn EK, Vilagos B, Richson U, Swaminanthan S, Bosnjak B, Bauer L, Kandasamy RK, Griesshammer IM, Kosack L, Schmitz F, Litvak V, Sissons J, Lercher A, Bhattacharya A, Khamina K, Trivett AL, Tessarollo L, Mesteri I, Hladik A, Merkler
D, Kubicek S, Knapp S, Epstein MM, Symer DE, Aderem A, Bergthaler A. The methyltransferase Setdb2 mediates virusinduced susceptibility to bacterial superinfection. Nat Immunol 2015; 16(1): 67-74

152. Yang J, Tian B, Sun H, Garofalo RP, Brasier AR. Epigenetic silencing of IRF1 dysregulates type III interferon responses to respiratory virus infection in epithelial to mesenchymal transition. Nat Microbiol 2017; 2(8): 17086

153. Meisel M, Hinterleitner R, Pacis A, Chen L, Earley ZM, Mayassi T, Pierre JF, Ernest JD, Galipeau HJ, Thuille N, Bouziat R, Buscarlet M, Ringus DL, Wang Y, Li Y, Dinh V, Kim SM, McDonald BD, Zurenski MA, Musch MW, Furtado GC, Lira SA, Baier G, Chang EB, Eren AM, Weber CR, Busque L, Godley LA, Verdú EF, Barreiro LB, Jabri B. Microbial signals drive preleukaemic myeloproliferation in a Tet2-deficient host. Nature 2018; 557(7706): 580-584

154. Zhang Q, Zhao K, Shen Q, Han Y, Gu Y, Li X, Zhao D, Liu Y, Wang C, Zhang X, Su X, Liu J, Ge W, Levine RL, Li N, Cao X. Tet2 is required to resolve inflammation by recruiting Hdac2 to specifically repress IL-6. Nature 2015; 525(7569): 389-393 